\title{
Implementing a new pedagogy in the nursing curriculum: Bachelor students' evaluation
}

\author{
Jan Gunnar Dale ${ }^{* 1}$, Bjørg Dale ${ }^{2}$ \\ ${ }^{1}$ Faculty of Health and Sport Sciences, University of Agder, Grimstad, Norway \\ ${ }^{2}$ Centre for Care Research, Faculty of Health and Sport Sciences, University of Agder, Grimstad, Norway
}

Received: April 30, 2017

DOI: $10.5430 /$ jnep.v7n12p98
Accepted: August 6, 2017

Online Published: August 10, 2017

\begin{abstract}
Background: Inspired by the work of Benner and colleagues at Carnegie Foundation, a new course in nursing was implemented in the first study year's curriculum in the bachelor program in nursing. The new nursing course included a shift from a lecture-only classroom based approach to a problem-based and case-based approach. Reflections and discussions in groups with fellow students and supervisors was the main activity. The aim of this study was to examine how the students experienced the new nursing course.

Methods: The survey study was conducted at a university in southern Norwegian. The sample consisted of students in two subsequent classes ( $\mathrm{n}=126$ and $\mathrm{n}=118$ ), who had followed the new study plan in the first study year and the traditional study plan in the second study year. An electronic survey, including questions concerning the extent, quality and usefulness of the study plans were examined.

Results: The students were, in general, satisfied with the new nursing course regarding the content and quality. The teachers' presence and ability to engage, challenge and facilitate reflection seemed to be decisive. Reflecting and discussing real-life patient cases in groups with fellow students and a supervisor was stimulating, motivating and useful for learning professional nursing. Conclusions: A problem based, case-based pedagogy might increase the students' preparedness for solving patient problems that they encounter in clinical settings. Cooperation and reflection in small groups with fellow students and the supervisor enhance nursing students' clinical reasoning skills, and might contribute to reduce the gap between theory and practice.
\end{abstract}

Key Words: Case-based, Clinical reasoning, Group studies, Nursing course, Problem-based, Survey

\section{INTRODUCTION}

Providing nursing care with flexibility integrates many sets of skills, including analytical skills, practical skills, collaborative skills, and ethics. ${ }^{[1]}$ Nurses' practice environment is often complex, chaotic and changing, which makes each day different and challenging. ${ }^{[1]}$ Capacity for critical thinking, clinical reasoning and problem solving are crucial prerequisites for providing advanced nursing practice. ${ }^{[2,3]}$ Hence, to enhance nurses' preparedness for handling a complex and demanding clinical reality after graduation, it is of utmost importance that educational institutions implement teaching and learning methods that facilitate students' critical thinking and clinical reasoning. ${ }^{[4]}$ Inspired by the work of Benner et al., ${ }^{[5]}$ radical changes were implemented in the nursing course in the curriculum at a university in southern Norway. The changes implied a shift from a traditional lectures based methodology to a student-active and problem based pedagogy, including case-based learning (CBL) and reflections in groups with other students and supervisors. ${ }^{[5-7]}$ The amount of traditional classroom lectures was reduced radically.

\footnotetext{
*Correspondence: Jan Gunnar Dale; Email: jan.g.dale@uia.no; Address: Faculty of Health and Sport Sciences, University of Agder, Grimstad, Norway.
} 
Although similar study plans might have been implemented in nursing education elsewhere in Norway, we have not been able to identify publications that describe experiences with such implementations in Norwegian contexts. Thus, the aim of this study was to examine bachelor students' experiences with an implemented student-active and problem based nursing course, in the first study year of bachelor in nursing.

\section{Background}

Studies report that newly graduated nurses are not very well prepared to handle the demands they face as professionals in complex clinical patient situations. ${ }^{[8,9]}$ Many students experience a prominent gap between education and practice because clinical practice is so different from what they learn in formal educational settings. ${ }^{[1,5]}$ This fact puts many challenges on educational institutions. They are responsible for curricula and pedagogic approaches that promote the students' clinical skills, clinical reasoning skills, and their ability to transfer the accumulated knowledge to solve patient problems in practice. ${ }^{[6]}$ As described by Benner et al., ${ }^{[5]}$ the traditional pedagogic approach inspired by behaviourist philosophy does not provide the best learning possibilities for nursing graduates' preparedness in real-life patient situations. This pedagogic approach, often inspired by the biomedical model, has formed the basis for nursing textbooks, which tend to divide knowledge into parts, objectify the patient and do not emphasize the importance of seeing the patient holistically. ${ }^{[1]}$ Further, these teacher-focused sessions might limit the students' ability to identify own learning needs. ${ }^{[2]}$ It is assumed that this approach is less appropriate for developing students' critical nursing skills and preparedness for practice.

The work presented by Benner et al., ${ }^{[5]}$ holds an alternative mode of pedagogical approach inspired by constructivist ideology, assuming that learning is a deeply mental process. ${ }^{[1]}$ Constructivist-based learning typically includes interactivity, problem-solving, clinical imagination, discussion and reflections on real-life patient scenarios in collaboration with peers. ${ }^{[6]}$ The traditional lecture-based teaching methodologies tend to be content-based and outcome focused, with emphasis on teaching facts, concepts and theory carried out in class-rooms with large groups of students, ${ }^{[10,11]}$ is characterized by passive information transition from educator to student. Students report that too much emphasis on theory and concepts in the nursing curriculum, at the expense of context and application to practice, might lessen their ability to apply the introduced concepts in clinical situation. ${ }^{[12]}$ On the other hand, a student-centred pedagogic approach, often termed as problem based learning (PBL), challenges students to possess self-directed activities towards solving the clinical problems, ${ }^{[2]}$ and to develop problem-solving abilities

Published by Sciedu Press which are critical for providing safe and effective nursing practice. ${ }^{[10]} \mathrm{CBL}$ is described as a method of PBL where the educational message is based on a patient story, and the students are offered a venue to relate class-room learned content to performance in professional practice. ${ }^{[13]}$ When using this pedagogic approach, the teacher's main role is to facilitate, guide and interact with students, ${ }^{[14]}$ and challenging them to think more deeply about complex processes and problems. ${ }^{[15]}$ To work with real patient cases, both theoretically and in simulated clinical laboratory environments, strengthens the students' ability to solve clinical patient problems because they must think, engage, reflect on prior knowledge and make their cognition visible. ${ }^{[1,5,6]}$ Working in teams with other students enables students to exercise, and develop critical thinking and problem-solving skills, which are acquired to prepare them for complex nursing practice. ${ }^{[16,17]}$ In addition, team based studies provide opportunities for developing the students' collaborative competence, and opportunities for self-reflection regarding their own role as a member of a professional team. ${ }^{[17]}$

Although closely related and often interchangeably used, critical thinking and clinical reasoning are not the same. According to Benner et al., ${ }^{[5]}$ education programs in nursing needs a change from the emphasis on critical thinking to clinical reasoning that includes critical thinking. In other words, critical thinking is an important part of clinical reasoning, as it involves the ability to use skilful thinking in the analyses, assessments and judgements in the process of clinical reasoning. ${ }^{[18]}$ Regarding professional nursing, clinical reasoning refers to the nursing process that consists of assessing, planning and implementing care based on identified patient needs. ${ }^{[4]}$ Thus, development of clinical reasoning skills is essential for delivering competent patient care. ${ }^{[4]}$

\section{Methods}

\subsection{The new nursing course and the setting}

A radical redesign of the nursing course in the first year's bachelor's curriculum was implemented at the university, starting in autumn 2012. The students' feed-back on the traditional lecture-based study plan in the nursing course during the previous years indicated dissatisfaction with the comprehensive amount of power-point based classroom lectures. The approach was found to be demotivating for learning nursing, and the content of the lectures was frequently viewed as inappropriate or insufficient for studying real-life patient problems. Consequently, a new nursing course was designed and implemented. During the first and second semester, the students work on various topics within the subject "Basic Nursing". The course consists of 16 different themes, and 10 of the themes include mandatory group meetings with co- 
students and supervisors, working on solving patient cases, presentations, and practical exercises related to simulated patient cases in the clinic laboratory. Work groups including 4-6 students in each are established at the start of the study. Two or three lectures are held as an introduction to each theme. A digital workbook with study questions related to the various themes and the syllabus is used for individual studies.

The two classes presented in this study, starting in 2012 (ref. C1) and 2013 (ref. C2) followed the new nursing course in the first year and the former traditional lecture-based nursing course in the second study year. Other courses in the curriculum, such as anatomy, physiology and pathophysiology, were still conducted as traditional class-room lectures. In this paper, the term "study plan" will sometimes be used, referring to the specific nursing course in the curriculum.

\subsection{The sample}

All students in two subsequent classes, C1 $(\mathrm{n}=262$, and C2 ( $n=275$ ) were in the beginning of the fourth study semester, invited to participate in an electronic survey for evaluating the new programme together with information about the study. At that time, the students had completed the first year studies following the new nursing course and second year studies following the former traditional plan.

\subsection{The questionnaire}

To examine the students' experiences of and opinions about the new nursing course, the questionnaire contained several items related to the course content, quality and to what degree the course was useful for studying nursing. A five-point Likert scale scoring system was used. The options ranged from "far too little" to "far too much" for the items reflecting quantity of lectures, assignments, and teachers' supervision. The options "very poor" to "very good" were used for rating the quality of lectures, supervision and the digital work book, and "not useful" to "very useful" for the items reflecting to what degree the teachers' supervision, the assignments, the digital work book and the group works, respectively, were perceived as appropriate. One additional question was asked on the extent to which the new nursing course contributed to learning professional nursing compared with the nursing course they had followed in the second year. Subsequently, the students were asked to comment and elaborate in their own words on how they experienced the new and former study plans' appropriateness for learning professional nursing.

\subsection{Analyses}

IBM SPSS statistical software version 22 was used to perform the statistical analyses. The significance level was set at $p<.05$. Descriptive analyses were used to present the distribution of student responses regarding the items in the questionnaire. To identify possible associations between different items, Spearman's rank correlations $\left(\mathrm{r}_{s}\right)$ were displayed.

The students' comments to the open question were summarized, and the most frequent and common statements are presented.

\subsection{Ethics}

The Norwegian Centre for Research Data (NSD) was consulted for advice regarding notification. They underlined that the study was not notifiable if collected data were completely anonymous, no e-mail addresses were available, and no sociodemographic or recognizable information were collected. This was the situation in the current study.

However, the information attached to the questionnaire underlined the participants' voluntariness and how the collected data were planned to be stored and used. Returned questionnaires were considered as consent to participate.

\section{RESULTS}

A total of $126(48.1 \%)$ students in C1 and 118 (42.9\%) students in $\mathrm{C} 2$ responded to the questionnaire. The students' scores on the items included in the questionnaire, reflecting the new nursing course, are presented in Table 1 (extent), Table 2 (quality), and Table 3 (usefulness).

Table 1. The students' opinions about the extent of lectures, group assignments, and the teachers' group supervision in the new study plan $(\mathrm{C} 1 ; \mathrm{n}=126)$ and $(\mathrm{C} 2 ; \mathrm{n}=118)$

\begin{tabular}{|c|c|c|c|c|c|c|c|}
\hline Questions & Class & $\begin{array}{l}\text { Far too } \\
\text { little } \\
\% \text { (n) }\end{array}$ & $\begin{array}{l}\text { Somewhat } \\
\text { too little } \\
\% \text { (n) }\end{array}$ & $\begin{array}{l}\text { Appropriate } \\
\% \text { (n) }\end{array}$ & $\begin{array}{l}\text { Somewhat } \\
\text { too much } \\
\% \text { (n) }\end{array}$ & $\begin{array}{l}\text { Far too } \\
\text { much } \\
\% \text { (n) }\end{array}$ & $\begin{array}{l}\text { Don't } \\
\text { know } \\
\% \text { (n) } \\
\end{array}$ \\
\hline \multirow{2}{*}{$\begin{array}{l}\text { What is your opinion about the extent of the } \\
\text { classroom lectures? }\end{array}$} & C1 & $5(6)$ & 21 (27) & 47 (60) & 22 (28) & $2(3)$ & $2(3)$ \\
\hline & $\mathrm{C} 2$ & $5(6)$ & 22 (25) & $49(55)$ & $18(20)$ & $3(3)$ & $3(3)$ \\
\hline \multirow{2}{*}{$\begin{array}{l}\text { What is your opinion about the extent of } \\
\text { group assignments? }\end{array}$} & C1 & 2 (3) & 15 (19) & $56(71)$ & 22 (28) & 2 (3) & 2 (3) \\
\hline & $\mathrm{C} 2$ & $1(1)$ & $22(24)$ & 79 (87) & $25(27)$ & $3(3)$ & $1(1)$ \\
\hline \multirow{2}{*}{$\begin{array}{l}\text { What is your opinion about the extent of } \\
\text { teacher's group supervision? }\end{array}$} & $\mathrm{C} 1$ & $10(12)$ & 30 (38) & 52 (65) & $5(6)$ & $1(1)$ & $2(3)$ \\
\hline & $\mathrm{C} 2$ & $6(7)$ & 36 (39) & $46(50)$ & $7(8)$ & $2(2)$ & $3(3)$ \\
\hline
\end{tabular}


Table 2. The students' opinions about the quality of the lectures, the teacher's group supervision and the digital workbook in the new study plan $(\mathrm{C} 1 ; \mathrm{n}=126)$ and $(\mathrm{C} 2 ; \mathrm{n}=118)$

\begin{tabular}{llllllll}
\hline Questions & Class & $\begin{array}{l}\text { Very } \\
\text { poor } \\
\text { \% (n) }\end{array}$ & $\begin{array}{l}\text { Fairly } \\
\text { poor } \\
\text { \% (n) }\end{array}$ & $\begin{array}{l}\text { Average } \\
\text { \% (n) }\end{array}$ & $\begin{array}{l}\text { Fairly } \\
\text { good } \\
\text { \% (n) }\end{array}$ & $\begin{array}{l}\text { Very } \\
\text { good } \\
\text { \% (n) }\end{array}$ & $\begin{array}{l}\text { Don't } \\
\text { know } \\
\text { \% (n) }\end{array}$ \\
\hline What is your opinion about the quality of & $\mathrm{C} 1$ & $2(3)$ & $11(14)$ & $36(46)$ & $46(59)$ & $2(3)$ & $2(2)$ \\
the classroom lectures? & $\mathrm{C} 2$ & $4(5)$ & $15(17)$ & $41(46)$ & $35(39)$ & $4(4)$ & $1(1)$ \\
What is your opinion about the quality of & $\mathrm{C} 1$ & $1(1)$ & $15(19)$ & $31(39)$ & $34(42)$ & $18(22)$ & $2(2)$ \\
teacher's group supervision? & $\mathrm{C} 2$ & $6(6)$ & $18(20)$ & $28(31)$ & $34(37)$ & $14(15)$ & $0(0)$ \\
What is your opinion about the quality of & $\mathrm{C} 1$ & $0(0)$ & $7(8)$ & $30(35)$ & $31(36)$ & $4(5)$ & $28(32)$ \\
the digital workbook? & $\mathrm{C} 2$ & $0(0)$ & $11(11)$ & $33(33)$ & $30(30)$ & $3(3)$ & $23(23)$ \\
\hline
\end{tabular}

Table 3. The students' opinions about the usefulness of the group assignments, the digital workbook, the teacher's group supervision and the group studies in general in the new study plan $(\mathrm{C} 1 ; \mathrm{n}=126)$ and $(\mathrm{C} 2 ; \mathrm{n}=118)$

\begin{tabular}{llllllll}
\hline Questions & Class & $\begin{array}{l}\text { Not } \\
\text { useful } \\
\text { \% (n) }\end{array}$ & $\begin{array}{l}\text { Not very } \\
\text { useful } \\
\text { \% (n) }\end{array}$ & $\begin{array}{l}\text { Average } \\
\text { \% (n) }\end{array}$ & $\begin{array}{l}\text { Fairly } \\
\text { useful } \\
\text { \% (n) }\end{array}$ & $\begin{array}{l}\text { Very } \\
\text { useful } \\
\text { \% (n) }\end{array}$ & $\begin{array}{l}\text { Don't } \\
\text { know } \\
\text { \% (n) }\end{array}$ \\
\hline To what degree were the group assignments & $\mathrm{C} 1$ & $1(1)$ & $22(27)$ & $17(21)$ & $39(48)$ & $19(24)$ & $2(3)$ \\
useful for learning nursing? & $\mathrm{C} 2$ & $6(6)$ & $21(23)$ & $22(24)$ & $41(44)$ & $9(10)$ & $1(1)$ \\
To what degree was the digital workbook useful & $\mathrm{C} 1$ & $3(3)$ & $16(18)$ & $34(39)$ & $22(26)$ & $1(1)$ & $25(29)$ \\
for learning nursing? & $\mathrm{C} 2$ & $2(2)$ & $15(15)$ & $33(33)$ & $23(23)$ & $2(2)$ & $24(24)$ \\
To what degree was the teacher's group & $\mathrm{C} 1$ & $2(2)$ & $18(23)$ & $26(33)$ & $34(42)$ & $19(24)$ & $1(1)$ \\
supervision useful for learning nursing? & $\mathrm{C} 2$ & $5(5)$ & $21(23)$ & $29(32)$ & $28(31)$ & $15(16)$ & $2(2)$ \\
To what degree was working in groups with & $\mathrm{C} 2$ & $5(5)$ & $21(23)$ & $29(32)$ & $28(31)$ & $15(16)$ & $2(2)$ \\
other students useful for own learning? & $\mathrm{C} 2$ & $7(8)$ & $14(15)$ & $26(28)$ & $37(40)$ & $16(17)$ & $0(0)$ \\
\hline
\end{tabular}

The association between students' opinions about the quality and the benefit of the teachers' group supervision was clearly supported among students in $\mathrm{C} 1\left(\mathrm{r}_{s}=.78 ; p<.01\right)$ and $\mathrm{C} 2$ $\left(\mathrm{r}_{s}=.86 ; p<.01\right)$. Those who found the cooperation with other students in the group sessions useful also found the group assignments useful $\left(\mathrm{C} 1: \mathrm{r}_{s}=.63 ; p<.01\right.$ and $\mathrm{C} 2: \mathrm{r}_{s}=$ $.73 ; p<.01)$ and motivating $\left(\mathrm{C} 1: \mathrm{r}_{s}=.44 ; p<.01\right.$ and $\mathrm{C} 2$ : $\mathrm{r}_{s}=.66 ; p<.01$ ) for studying nursing. Those who perceived the group assignments as the most extensive had the greatest benefit from the study groups with fellow students $\left(\mathrm{C} 1: \mathrm{r}_{s}=\right.$ $.31 ; p<.01$ and $\left.\mathrm{C} 2: \mathrm{r}_{s}=.56 ; p<.01\right)$, but these students also had the greatest benefit from working with the assignments to acquire nursing knowledge $\left(\mathrm{C} 1: \mathrm{r}_{s}=.41 ; p<.01\right.$ and $\mathrm{C} 2$ : $\left.\mathrm{r}_{s}=.52 ; p<.01\right)$.

Table 4 reflects the students' opinions about the appropriateness of the new and old nursing course to acquire nursing knowledge.

Table 4. The students' opinions about the new and the traditional study plan for learning nursing - a comparison $(\mathrm{C} 1 ; \mathrm{n}=$ $126)$ and $(\mathrm{C} 2 ; \mathrm{n}=118)$

\begin{tabular}{llllllll}
\hline Question & Class & $\begin{array}{l}\text { Traditional } \\
\text { nursing course } \\
\text { much better } \\
\text { \% (n) }\end{array}$ & $\begin{array}{l}\text { Traditional } \\
\text { nursing course } \\
\text { a little better } \\
\text { \% (n) }\end{array}$ & $\begin{array}{l}\text { No pre- } \\
\text { ferences } \\
\text { \% (n) }\end{array}$ & $\begin{array}{l}\text { New nursing } \\
\text { course a little } \\
\text { better } \\
\text { \% (n) }\end{array}$ & $\begin{array}{l}\text { New nursing } \\
\text { course much } \\
\text { better } \\
\text { \% (n) }\end{array}$ & $\begin{array}{l}\text { Don't } \\
\text { know } \\
\text { \% (n) }\end{array}$ \\
\hline $\begin{array}{l}\text { The appropriateness of the new } \\
\text { and the traditional nursing courses } \\
\text { for learning nursing }\end{array}$ & $\mathrm{C} 1$ & $7(8)$ & $20(24)$ & $34(41)$ & $18(22)$ & $12(14)$ & $8(10)$ \\
\hline
\end{tabular}

This question, comparing the new and old study plan, was further commented on by the students. The most frequent comments in both classes regarding the new study plan focused on the benefit of discussing and reflecting together with fellow students in organized groups, and the teachers' presence and supervision in the group sessions. However, the teachers' availability, ability to engage, to challenge, and facilitate for reflection and discussion was clearly emphasized. 
Many students appreciated the student-active approach, although some of them thought it was too many and frequent group meetings, and that sometimes not much came out of them. The group discussions could easily become partly small talk if the structure was too loose. Preparation and structure were considered as important. However, the most frequent remarks regarding the new study plan indicated an overall satisfaction compared to the traditional old study plan. Although there was some variation, the comments indicated that the traditional lecture-based approach tended to be repetitive and passivating. However, class-room lectures given by dedicated, engaged and practice-oriented teachers were also highlighted as a positive source of inspiration and learning.

\section{Discussion}

The aim of the present study was to explore bachelor students' experiences with a newly implemented student-active nursing course in the first study year. The data also included the students' opinions about the new and former study plan's appropriateness for gaining nursing knowledge and practice insight.

\subsection{Problem based versus lecture based studies}

Although the number of class lectures was dramatically reduced in the new nursing course, it is a general impression that the students perceived the amount of class room lectures to be appropriate. The students rated the quality of lectures as averagely or fairly good, which might indicate that the reduced number of lectures had improved the quality. Some comments on the open question also indicate that the students prefer few but high-quality and focused lectures over many lectures with less quality. A student-active and problem based pedagogic approach is, in several previous studies, found to be fundamental to develop the students' clinical reasoning skills and to enhance their readiness for solving patient problems in clinical settings. ${ }^{[4,5,11,14,19-21]}$

A systematic meta-analysis of studies focusing on the effectiveness of PBL for development of nursing students' critical thinking conclude that the PBL students score significantly higher on critical thinking compared with students who had followed traditional lectures. ${ }^{[22]}$ Similar results were found in Yoo and Park's ${ }^{[10]}$ study, concluding that CBL was the most effective approach for graduate nurses' development of problem-solving abilities. Le Roux and Khanyile ${ }^{[19]}$ accentuate that when using the problem-based approach, it is possible to combine the strengths of the traditional methods in dealing with large class sizes with a focus on clinical practice. Their argument is the provision of opportunities for students to try out in a safe classroom environment several alternative solutions to dilemmas they will meet in real life situations. The students are provided with opportunities to improve their critical thinking and clinical reasoning skills. ${ }^{[20]}$ According to Benner et al., ${ }^{[5]}$ the foundation of professional nursing practice is constituted by reflection, and CBL is found to empower students' attitudes towards patient care, to enhance their self-confidence and self-evaluation, and help them acknowledge the responsibility for own learning. Similar arguments are stated by Kantar and Massouh. ${ }^{[7]}$

\subsection{The benefits from studies and reflection in groups}

Working in teams with other students was considered as appropriate and helpful for gaining nursing knowledge. In particular, discussing and reflecting on real-life patient cases with fellow students in small groups was useful for gaining a deeper understanding of nursing practice. A benefit from working and studying in teams is the opportunity to share knowledge to solve patient problems, and previous research has also shown that feed-back from teammates and the supervisor develops the students' problem-solving skills. ${ }^{[17]}$ Reflections and problem solving related to case seminars with fellow students may also improve the students' cooperation skills,,${ }^{[1]}$ which is particularly valuable for professions such as nursing that often include teamwork with various professions. Harmon and Thompson, ${ }^{[4]}$ however, found unexpected low scores among the students regarding the effects of group collaboration and reflections on their clinical reasoning skills. One explanation suggested was that the students were inexperienced with group learning and lacked skills assumed to be necessary for successful collaboration. The composition of the student groups means involving individuals with various backgrounds, experiences and preferences, which might have impacts on the group dynamic. Taken this into consideration, the positive experiences among the students in the current study might be promising as group studies were introduced as a major activity from the very beginning of their education. However, when comparing the students' perceptions of the new and the traditional lecturebased study plan, many of the respondents appeared to have positive experiences with the traditional plan as well. One explanation to this might be due to variation in the students' motivation, preparedness and previous experiences of working in groups. Individual studies and preparedness before the group meetings, including reflection on the themes to be focused in the group and reading of syllabus, essential to benefit from the group studies. ${ }^{[17]}$ A considerable amount of compulsory group assignments, mostly focusing on patient cases, was part of the group studies, including written and oral presentations. Although these were laborious tasks, most students found them useful. Assignments related to current, corresponding course contents are found to help students be engaged in reflective practice and construction of 
knowledge. [23]

The educational value of collaborative, CBL was also strongly supported by Thurman et al. ${ }^{[24]}$ and no relationship between the students evaluation of their own learning outcomes and how well they knew the group members was found in that particular study. Working in groups with other students might also provide opportunities for self-reflection on their own role and position in the team. ${ }^{[17]}$ According to problem-solving abilities, knowledge and clinical performance, Kim et al. ${ }^{[17]}$ investigated the effects of team-based studies compared to traditional lectures. The benefits of team-based studies were clearly demonstrated. However, they point out that the purpose of using this approach should not only be to cut educational costs, but the appropriateness to achieve the best learning outcomes.

\subsection{The teacher's role and competence}

Some of the teachers who had been responsible for supervising the student groups were quite inexperienced and not very prepared for this role, which might be another explanation to why some students' experiences of the group studies were variable. A stringent structure and predictable goals during the group studies are found to be important. ${ }^{[17]}$ The extent of the teachers' preceptorship or supervision in the groups was perceived as adequate by most of the students in the current study, although some of the students would prefer more teacher attendance, interaction and support. In PBL, the teachers act as facilitators and guides, encouraging students to develop skills and knowledge by asking appropriate questions. ${ }^{[14]}$ The teachers' ability to engage, motivate and facilitate reflections and clinical reasoning might be a critical prerequisite for positive learning experiences in PBL. Appropriate teacher interventions increase the students' case reflections to a higher level and may help them to engage in mastering the case content. According to Ramaekers et al. ${ }^{[25]}$ teachers can, in most cases, effectively combine their several roles. For example, they might provide information and guidance when needed and stimulate students to reflect, analyse, and broaden their scope by relating practical patient cases to general theoretical assumptions. ${ }^{[25]}$ According to Tanner, ${ }^{[26]}$ there is substantial evidence that guidance in reflection enhances students' reflection habits and skills and improves their clinical reasoning, particularly if such guidance occurs in a climate of colleagueship (fellowship) and support.

\subsection{Limitation and strength of this study}

A limitation of this study might be that the sample size was relatively small, and the survey studies were conducted shortly after the new study programme was implemented. However, a strength might be that data were collected from two separate and subsequent classes, and all students had experiences from the new and the traditional study plan in nursing. In addition, they had completed two periods of clinical studies, and had experiences regarding the study plans' appropriateness for learning in practical settings. Nevertheless, further studies including supplementary classes are required to obtain a more comprehensive and reliable impression of the students' perceptions and experiences. In addition, the implications of the new study plan for students' clinical practice should be more comprehensively investigated, as well as the long-term effects after graduation.

\section{Conclusions}

A general impression was that the students perceived the new, case-based nursing course in the curriculum to be useful and motivating for studying nursing. The emphasis on group studies was found to be fruitful, although some of the students seemed to prefer more class-room lectures. The individual variations in preferences, motivation and previous experiences might be one explanation to this. However, the role and quality of the teachers' guidance in the group sessions seemed to be crucial for positive experiences and learning outcomes, which underline the importance of the educator's preparedness and pedagogic competence. Improving students' critical thinking and clinical reasoning skills might affect the quality and play a vital role in the outcomes of nursing care to patients in practice. Many previous studies internationally have shown that studying and reflecting on patient problems in supervised student groups helps to develop the students' clinical reasoning and collaborative skills. However, there is a lack of publications from a Norwegian context describing nursing students' experiences with this pedagogical approach. Therefore, this study complements existing knowledge.

\section{CONFLicts OF INTEREST Disclosure}

The authors declare that there is no conflict of interest.

\section{REFERENCES}

[1] Handwerker SM. Transforming nursing education: a review of current curricular practices in relation to Benner's latest work. Int J Nurs Educ Scholarsh. 2012; 9(1): 1-19. https ://doi.org/10.1515/
$1548-923 X .2510$

[2] Martyn J, Terwijn R, Kek MYCA, et al. Exploring the relationships between teaching, approaches to learning and critical thinking in a problem-based learning foundation nursing course. Nurse Educ 
Today. 2014; 34: 829-835.

[3] Klaeson K, Berglund M, Gustavsson S. The character of nursing students' critical reflection at the end of their education. J Nurs Educ Pract. 2017; 7(5): 55-61. https ://doi.org/10.5430/jnep.v7n $5 \mathrm{p} 55$

[4] Harmon MM, Thompson C. Clinical reasoning in pre-licensure nursing students. Teach Learn Nurs. 2015; 10: 63-70. https: //doi.org/10.1016/j.teln.2014.12.001

[5] Benner P, Sutpen M, Leonard V, et al. Educating Nurses. A Call for Radical Transformation. San Francisco: Jossey-Bass; 2010.

[6] Kantar L. Incorporation of constructivist assumptions into problembased instruction: a literature review. Nurse Educ Pract. 2014; 14(3): 233-241. https://doi.org/10.1016/j.nepr.2013.08.010

[7] Kantar L, Massouh A. Case-based learning: what traditional curricula fail to teach. Nurse Educ Today. 2015; 35(8): e8-e14. https: //doi.org/10.1016/j.nedt.2015.03.010

[8] Nematollahi R, Isaac JP. Bridging the theory practice gap: a review of Graduate Nurse Program (GNP) in Dubai, United Arab Emirates. Int Nurs Rev. 2012; 59: 194-199. https ://doi.org/10.1111/j . 1466-7657.2011.00949.x

[9] Whitehead B, Holmes D. Are newly qualified nurses prepared for practice? Nurs Times. 2011; 107(19-20): 20-23.

[10] Yoo MS, Park JH. Effect of case-based learning on the development of graduate nurses' problem-solving ability. Nurse Educ Today. 2013; 34(1): 47-51. http://doi.org/10.1016/j.nedt. 2013. 02.014

[11] Günüsen NP, Serçekus P, Edeer AD. A Comparison of ProblemBased and Traditional Education on Nursing Students' Locus of Control and Problem-Solving Skills. Int J Nurs Knowl. 2014; 25(2): 110-115. https://doi.org/10.1111/2047-3095.12024

[12] Ward K, Procter PM, Woolley N. Creating the balance in the nursing curriculum. Nurse Educ Pract. 2004; 4: 287-291. http: //doi.org/10.1016/j.nepr.2004.07.005

[13] Harman T, Bertrand B, Greer A. Case-Based Learning Facilitates Critical Thinking in Undergraduate Nutrition Education: Students Describe the Big Picture. J Acad Nutr Diet. 2015; 115(3): 378-388. https://doi.org/10.1016/j.jand.2014.09.003

[14] Prosser M, Sze D. Problem-based learning: students learning experiences and outcomes. Clin Ling Phon. January-February 2014; 28(1-2): 112-123. https://doi .org/10.3109/02699206. 2013. 820351

[15] Hawks SJ. The flipped classroom: now or never? AANA J. 2014; 82(4): 264-269. PMid:25167605
[16] Corbridge SJ, Corbridge T, Tiffen J, et al. Implementing team-based learning in a nurse practitioner curriculum. Nurse Educ. 2013; 38(5): 202-205. https : //doi .org/10.1097/NNE. Ob013e3182a0e416

[17] Kim HR, Song Y, Lindquist R, et al. Effects of team-based learning on problem-solving, knowledge and clinical performance of Korean nursing students. Nurse Educ Today. 2016; 38: 115-118. https://doi.org/10.1016/j.nedt.2015.12.003

[18] Alfaro-Lefevre R. Critical thinking, clinical reasoning, and clinical judgment: A practical approach, 5th ed. St. Louis, MO: Elsevier Saunders; 2011.

[19] Le Roux LC, Khanyile TD. A cross-sectional survey to compare the competence of learners registered for the Baccalaureus Curationis programme using different learning approaches at the University of the Western Cape. J Democrat Nurs Org South Africa (DENOSA). 2012; 34(1): 7.

[20] Forsgren S, Christensen T, Hedemalm A. Evaluation of the case method in nursing education. Nurse Educ Pract. 2013; 14(2): 164169. https://doi.org/10.1016/j.nepr.2013.08.003

[21] Choi E, Lindquist R, Song Y. Effects of problem-based learning vs. traditional lecture on Korean nursing students' critical thinking, problem-solving, and self-directed learning. Nurse Education Today. 2014; 34(1): 52-56. https://doi .org/10.1016/j.nedt. 2013. 02.012

[22] Kong LN, Qin B, Zhou YQ. The effectiveness of problem-based learning on development of nursing students' critical thinking: A systematic review and meta-analysis. Int J Nurs Stud. 2014; 51(3): 458469. PMid:23850065 https://doi.org/10.1016/j.ijnurstu .2013 .06 .009

[23] Josephsen JM. Evidence-based reflective teaching practice: a preceptorship course example. Nurs Educ Perspect. 2013; 34(1): 8-11. PMid:23586198 https ://doi .org/10.5480/1536-5026-34.1. 8

[24] Thurman J, Volet SE, Bolton JR. Collaborative, case-based learning: how do students actually learn from each other? J Vet Med Educ. 2009; 36(3): 297-304. PMid:19861718 https://doi.org/10.3 138/jvme.36.3.297

[25] Ramaekers S, Keulen H, Kremer W. Effective teaching in case-based education: patterns in teacher behaviour and their impact on the students' clinical problem-solving and learning. Int $\mathbf{J}$ Teach Learn High Educ. 2011; 23(3): 303-313. https : //doi .org/10.1016/j . nedt. 2015.03 .010

[26] Tanner SA. Thinking Like a Nurse: A Research-Based Model of Clinical Judgment in Nursing. J Nurs Educ. 2006; 5(6): 204-211. http://www.researchgate.net/publication/7003793 